\title{
PENGENALAN TEKNOLOGI INFORMASI PADA UMKM TEH KELOR AGAR MAMPU BERSAING DI MASA PANDEMI COVID-19
}

\author{
Sri Karnila ${ }^{* 1}$, Neni Purwati ${ }^{2}$, Hendra Kurniawan ${ }^{3}$, Nurjoko ${ }^{4}$ \\ 1,2,3,4 Institut Informatika dan Bisnis Darmajaya \\ e-mail: *srikarnila dj@darmajaya.ac.id ${ }^{1}$,nenipurwati87@darmajaya.ac.id ${ }^{2}$, \\ hendra.kurniawan@darmajaya.ac.id³ ${ }^{3}$,nurjoko@darmajaya.ac.id4
}

\begin{abstract}
The COVID-19 pandemic has had a very significant impact on all lines of human life. Usaha Mikro Kecil dan Menengah (UMKM) which were originally able to conduct sales conventionally through stalls or shops, which with limitations must transform to selling online. The method used is the activity socialization stage, preparation stage, implementation stage and reporting stage. Pengabdian Kepada Masyarakat (PKM) activity in Pidada Village, Panjang District, Bandar Lampung Regency, we carried out activities on developing UMKMs based on local wisdom, by providing an introduction to the use of information technology. Kelor tea is one of the SMEs in Pidada village which in its production process empowers local women to increase the economic income of Pidada villagers. During PKM at UMKM Teh Kelor we made several innovations, packaging by labeling and branding products, as well as marketing products online. The use of information technology for the sale of Moringa tea is carried out so that MSMEs of Moringa Tea are able to compete during this COVID-19 Pandemic.
\end{abstract}

Keywords: UMKM Teh Kelor, COVID-19 Pandemic, Labelling, Online Sales.

\section{Abstrak}

Pandemi COVID-19 memberikan dampak sangat signifikan pada semua lini kehidupan manusia. Demikian pula pada Usaha Mikro Kecil dan Menengah(UMKM) yang semula dapat melakukan penjualan secara konvensional melalui warung atau toko, yang dengan keterbatasannya harus bertransformasi melakukan penjualan secara online. Metode yang digunakan adalah tahap sosialisasi kegiatan, tahap persiapan, tahap pelaksanaan dan tahap pelaporan. Selama kegiatan Pengabdian kepada Masyarakat (PKM) di Desa Pidada Kecamatan Panjang Kabupaten Bandar Lampung, kami melakukan kegiatan pada pengembangan UMKM berbasis kearifan lokal, dengan memberikan pengenalan penggunaan teknologi informasi. Teh Kelor merupakan salah satu UMKM desa Pidada yang dalam proses produksinya memberdayakan ibu-ibu setempat untuk menambah pendapatan ekonomi warga desa Pidada. Selama PKM di UMKM Teh Kelor kami membuat beberapa inovasi, pengemasan dengan memberi label dan membuat branding produk, serta pemasaran produk secara online. Penggunaan teknologi informasi untuk penjualan teh kelor dilakukan agar UMKM Teh Kelor mampu bersaing di masa Pandemi COVID-19 ini.

Kata kunci: UMKM Teh Kelor, Pandemi COVID-19, Pelabelan, Penjualan Online.

\section{PENDAHULUAN}

Pandemi COVID-19 memberikan dampak sangat signifikan pada semua lini kehidupan manusia. Semua prilaku manusia dibatasi untuk melakukan kegiatan sehari-hari, demikian pula kegiatan Usaha Mikro Kecil dan Menengah(UMKM) yang semula dapat melakukan penjualan secara konvensional melalui warung atau toko, sekarang sudah tidak efektif dikarenakan pembeli sudah jarang melakukan pembelian di warung atau toko, karena larangan harus mengurangi kegiatan di luar rumah jika tidak diperlukan, sehingga UMKM dituntut untuk bertransformasi melakukan penjualan secara online. Namun hal tersebut tidak 
dapat dilakukan oleh semua masyarakat pelaku UMKM, masih banyak UMKM yang memiliki keterbatasan pengetahuan untuk dapat melakukan transformasi digital dengan pemanfaatan teknologi informasi. Melihat betapa pentingnya percepatan proses transformasi tersebut, maka kami melakukan kegiatan Pengabdian Kepada Masyarakat(PKM) pada UMKM.

Kebijakan pemerintah dalam pengembangan pangan lokal dituangkan dalam UU No. 18 Tahun 2012 pasal 41 dan 42. Kebijakan penganekaragaman pangan sebagaimana dimaksud dalam Pasal 41 antara lain adalah pengoptimalan pangan lokal, pengembangan teknologi usaha pengembangan pangan lokal, dan pengembangan industry berbasis pangan lokal. Teh Kelor merupakan salah satu UMKM desa Pidada yang dalam proses produksinya memberdayakan ibu-ibu setempat untuk menambah pendapatan ekonomi warga desa Pidada. Selama kegiatan Pengabdian kepada Masyarakat (PKM) di Desa Pidada Kecamatan Panjang Kabupaten Bandar Lampung, kami melakukan kegiatan yang fokus pada pengembangan UMKM berbasis kearifan lokal, dengan memberikan pengenalan penggunaan teknologi informasi. UMKM Teh Kelor ini masih menggunakan penjualan produk melalui warung atau toko, namun di masa pandemi COVID-19 pendapatannya mengalami penurunan yang signifikan. Untuk tetap mampu bersaing UMKM ini harus mengubah cara penjualan konvensional dengan menggunakan teknologi informasi. Oleh karena itu tujuan PKM yang kami lakukan dapat dilaksanakan sesuai dengan kebutuhan dari UMKM dengan memberikan pelatihan pengenalan teknologi informasi, pengemasan dan pelabelan produk, membuatkan branding produk, serta melakukan penjualan produk secara online. PKM ini diharapkan dapat membantu pelaku usaha dalam menghadapi lesunya perekonomian selama masa Pademi Covid-19 serta dapat menunjang kegiatan pemasarannya di era digital guna meningkatkan penjualan.

1) Branding Produk

Produk unik dengan kemasan menarik tidak cukup untuk menarik minat konsumen, sehingga diperlukan branding untuk membangun image positif. Menurut Nastain (2017) menuliskan bahwa brand tidak hanya sekedar nama dan logo, tetapi brand juga merupakan janji suatu perusahaan kepada pelanggan untuk memberikan apa yang menjadi prinsip brand tersebut. Brand tidak hanya sebagai identitas tetapi juga ada nilai-nilai yang ingin disampaikan kepada konsumen. Janji perusahaan untuk memberikan manfaat fungsional, emosional, ekspresi diri dan social sehingga brand dinilai unik dan berbeda dari produk lain oleh konsumen. Tahap selanjutnya adalah terwujudlah loyalitas pelanggan((Panuntun Utami, 2021). 
Membangun brand image pangan lokal untuk UMKM memerlukan suatu kajian sehingga diperoleh konsep branding yang tepat untuk mengangkat pamor pangan lokal. Konsep branding untuk pangan lokal dalam kajian ini difokuskan pada sisi produk. Produk pangan lokal UMKM sebenarnya memiliki kualitas rasa dan mutu yang bagus. Atribut produk menjadi perhatian dalam branding karena yang pertama dilihat konsumen adalah bentuk visual produk. Salah satu atribut produk yang cukup menonjol adalah kemasan. Produk yang secara visual dapat dilihat dan dirasakan konsumen adalah bentuk, kemasan, manfaat, dan rasa. Keindahan dan keunikan produk dapat divisualisasi melalui kemasan. Oleh karena itu kemasan yang unik, menarik, merk dan logo yang mudah diingat dapat digunakan sebagai strategi branding pangan lokal(Arifudin et al., 2021).

\section{2) Pengemasan Produk}

Menurut Andini dan Anggraeni(2016) bahwa daya tarik produk tidak hanya dilihat dari rasa saja, melainkan juga dari kemasan produk. Menurut Ahmad et al.(2014) dan Susetyarsi(2012) bahwa pengemasan dibuat semenarik mungkin agar dapat menarik minat pembeli. Menurut Suhardi(2019) bahwa kemasan juga dapat dijadikan sebagai sebuah media komunikasi antara produsen dengan konsumennya, sehingga kemasan yang baik merupakan kemasan yang mencantumkan informasi-informasi mengenai hal-hal apa saja yang diketahui oleh calon pembeli sehingga pembeli dapat dengan mudah mengenali produk yang dibeli melalui kemasannya(Suprayogi et al., 2021).

Kemasan yang dirancang dengan baik dapat membangun ekuitas merek dan mendorong penjualan. Kemasan adalah bagian pertama produk yang dihadapi pembeli dan mampu menarik atau mengalihkan pembeli. Pengemasan suatu produk biasanya dilakukan oleh produsen untuk dapat merebut minat konsumen terhadap pembelian barang. Produsen berusaha memberikan kesan yang baik pada kemasan produknya. Kemasan harus memberikan kesan terbaik pada pandangan pertama konsumen, karena kesan terbaik itulah yang akan sangat mempengaruhi keputusan konsumen untuk membeli atau meninggalkan produk tersebut(Apriyani et al., 2021).

\section{3) Pelabelan Produk}

Label pada kemasan sering kali diabaikan oleh pelaku Usaha Mikro Kecil dan Menengah (UMKM) di Indonesia. Padahal dalam Peraturan Pemerintah Nomor 69 tahun 1999 telah mengatur tentang kewajiban mencantumkan label pada kemasan pangan. Oleh karena 
itu pelaku UMKM perlu untuk memberikan prioritas dalam hal manajemen produk khususnya labeling pada kemasan produk(Lusianingrum et al., 2021).

Label merupakan bagian dari produk itu sendiri berupa penjelasan bentuk gambar, atau kata/ tulisan yang mempunyai fungsi informatif tentang produk dan sipenjual. Label pada dasarnya berisikan penjelasan berupa merek produk, bahan baku, isi produk, kandungan gizi, masa kedaluwarsa, berat neto dan legalitas produknya. Pelabelan pada kemasan produk sangat penting bagi pelaku bisnis yang bergerak dibidang industri makanan. Karena hal ini dapat dijadikan untuk media promosi bagi pelaku usaha untuk memasarkan dan mengembangkan produksinya. Industri makanan ringan dari tahun ketahun semakin berkembang di Indonesia. Hal tersebut menjadikan banyak pelaku bisnis mencoba untuk melakukan bisnis dengan memproduksi makan ringan baik dalam penjualan ataupun memproduksi produk makanan ringan itu sendiri. Tetapi sebagian pelaku bisnis banyak yang tidak memahami pentingnya pelabelan pada kemasan produknya(Dumadi et al., 2021).

4) Pemasaran dan Penjualan Produk

Faktor yang paling penting untuk mencapai keberhasilan dalam menjalankan usaha adalah pemasaran. Dalam proses pemasaran pelaku usaha berusaha untuk mengenalkan produk kepada konsumen. Beberapa pendapat mengatakan tentang pengertian pemasaran produk adalah suatu kegiatan menganalisis pasar, memberikan produk ke konsumen dan menerima umpan balik. Menurut Kleindl dan Burrow (2005) berpendapat bahwa Digital Marketing merupakan suatu proses perencanaan dan pelaksanaan dari konsep, ide, harga, promosi dan distribusi. Sederhananya dapat diartikan sebagai pembangunan dan pemeliharaan hubungan yang saling menguntungkan antara konsumen dan produsen. Tujuan dari digital marketing ini salah satunya untuk mencapai target pemasaran produk. Digital marketing ini dapat dilakukan dengan cara memasarkan produk menggunakan media sosial. Media sosial adalah media digital dengan ruang dan waktu yang tidak terbatas dan digunakan sebagai tempat realitas sosial untuk berinteraksi. Media sosial yang digunakan untuk pemasaran ini adalah instagram dan facebook(Fauzi et al., 2021).

Pemasaran dan penjualan online diharapkan dapat memperluas wilayah pemasaran dan dapat meningkatan penjualan. Para UMKM perlu mendapatkan pendampingan untuk merubah cara penjualannya yang saat ini masih konvensional menjadi penjualan yang berbasis digital atau dengan kata lain melakukan perdagangan elektronik (e-commerce). Menurut Armstrong and Kotler(2015) menyampaikan bahwa E-commerce adalah saluran online melalui komputer, dapat digunakan pelaku bisnis menjalankan aktifitas bisnisnya juga 
konsumen untuk mendapatkan informasi terkait hal tersebut yang diawali dengan proses memberi jasa informasi pada konsumen dalam penentuan pilihan(Surenggono et al., 2021).

\section{METODE}

Kegiatan pengabdian kepada masyarakat ini dilakukan pada UMKM Teh Kelor yang berada di desa Pidada kecamatan Panjang kota Bandar Lampung dengan menerapkan metode 4(empat) tahap, antara lain sebagai berikut:

1. Tahap Sosialisasi

Sosialisasi pelaksanaan PKM dilakukan dengan mengunjungi, meminta ijin dan menyampaikan tujuan kegiatan dan kepada pemilik UMKM oleh tim pengabdi.

\section{Tahap Perencanaan}

Proses perencanaan kegiatan PKM dimulai dengan membuat schedule pelaksanaan, menyiapkan presensi, dan mengatur skenario pelaksanaan kegiatan dikarenakan pelaksanaan dilakukan di masa pandemi COVID-19.

3. Tahap Pelaksanaan

a. Pelatihan pengenalan pentingnya teknologi informasi untuk mampu bersaing di masa pandemi COVID-19 kepada masyarakat, agar perekonomian desa Pidada mengalami peningkatan.

b. Desain branding produk Teh Kelor dilakukan oleh tim untuk membantu membangun brand image yang baik pada masyarakat terhadap produk UMKM ini. Branding ini dibuat dengan mengubah kemasan yang lama menjadi kemasan yang modern, dan membuatkan pelabelan produk teh kelor.

c. Pelatihan pembuatan akun pemasaran dan penjualan produk pada media sosial yaitu facebook dan Instagram.

4. Tahap Pelaporan

Pada tahap ini pengabdi menyusun laporan dari tahapan awal kegiatan hingga tahapan akhir kegiatan.

\section{HASIL DAN PEMBAHASAN}

Pelaksanaan kegiatan PKM ini dilakukan selama satu bulan, diawali dengan pelatihan pengenalan teknologi informasi kepada pemilik UMKM Teh Kelor dan masyarakat desa Pidada, yang dihadiri dan diikuti sebanyak 20 orang. Mengingat masih dalam masa pandemi, pada pelaksanaan pelatihan ini tetap memperhatikan dan menerapkan protokol kesehatan sesuai anjuran pemerintah (memakai masker, menjaga jarak dan mencuci tangan). Kegiatan 
ini dilakukan selama 2 jam dalam sehari mengingat keterbatasan tempat pada rumah pemilik UMKM Teh Kelor, dan keterbatasan mengumpulkan warga di masa pandemi ini. Pengabdi memberikan penjelasan tentang ecommerce, pemasaran dan penjualan online, kemudian tentang media sosial, manfaat media sosial dan proses pemasaran. Proses pemasaran berupa identifikasi kebutuhan dan keinginan pasar, segmentasi, targeting dan positioning, bauran pemasaran, bauran pemasaran elektronik dan kepuasan konsumen. Selain itu pengabdi juga memberikan materi cara membuat akun di media sosial yaitu facebook dan Instagram sebagai media melakukan pemasaran dan penjualan produk.

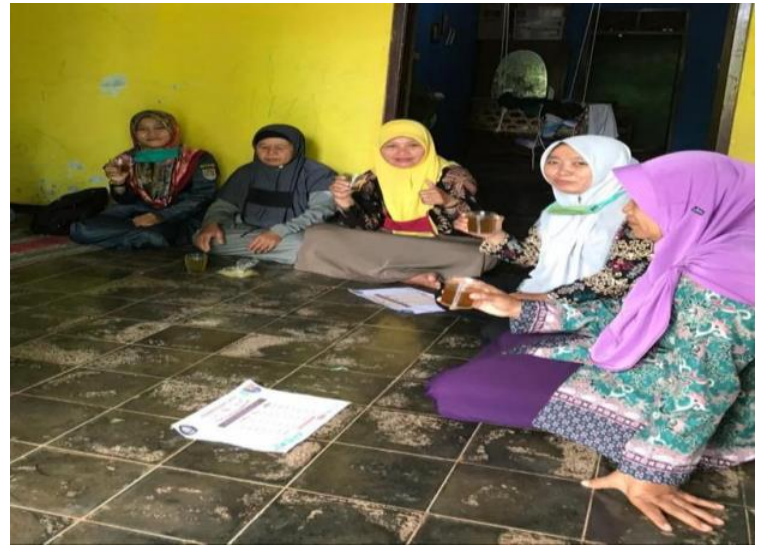

Gambar 1 Peserta pelatihan ibu-ibu

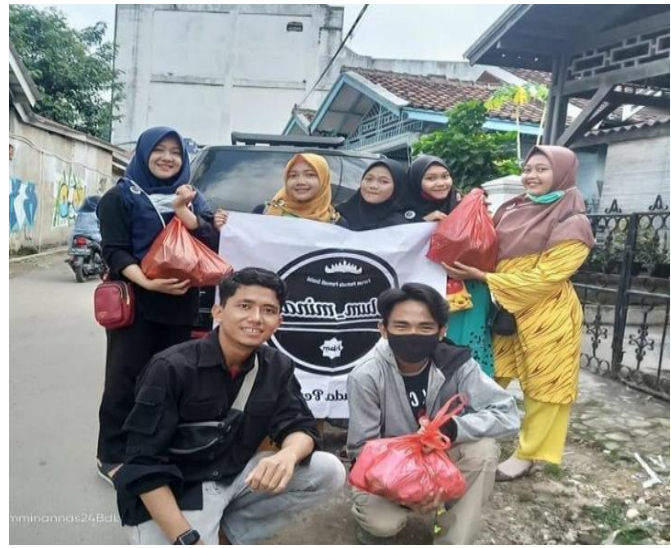

Gambar 2 Peserta pelatihan muda-mudi

Selanjutnya sebagai pengabdi yang mengetahui bahwa UMKM Teh Kelor sebagai pelaku bisnis yang ingin berkembang dan memperoleh pencapaian dan peningkatan pendapatan, maka kami memberikan materi pentingnya membangun branding agar produk yang dihasilkan oleh UMKM ini dapat diterima oleh masyarakat luas dengan brand image yang baik. Untuk membangun brand image tersebut maka kami membuatkan desain kemasan dan label. 

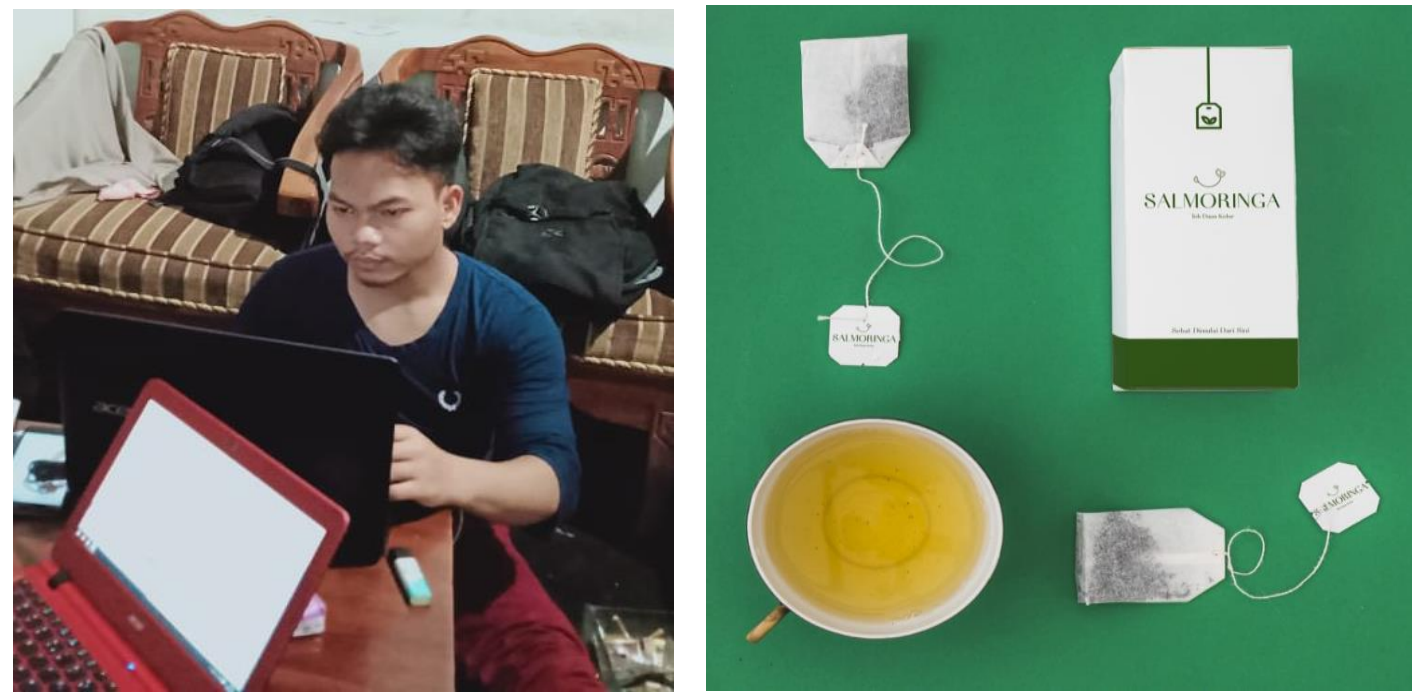

Gambar 3 Membuat Desain branding produk Teh Kelor

Adapun kemasan produk akan diubah menggunakan plastik Standing Pouch Klip yang semula menggunakan plastik biasa saja. Berikutnya pembuatan label dimulai dengan membuat sketsa secara digital, menggunakan beberapa software dan aplikasi, diantaranya Adobe Photoshop, CorelDraw dan Canva, lalu dipresentasikan kepada pemilik UMKM Teh Kelor.

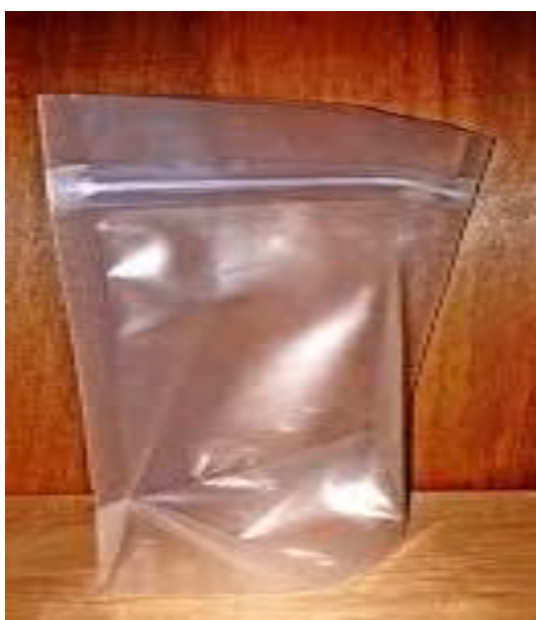

Gambar 4 kemasan produk

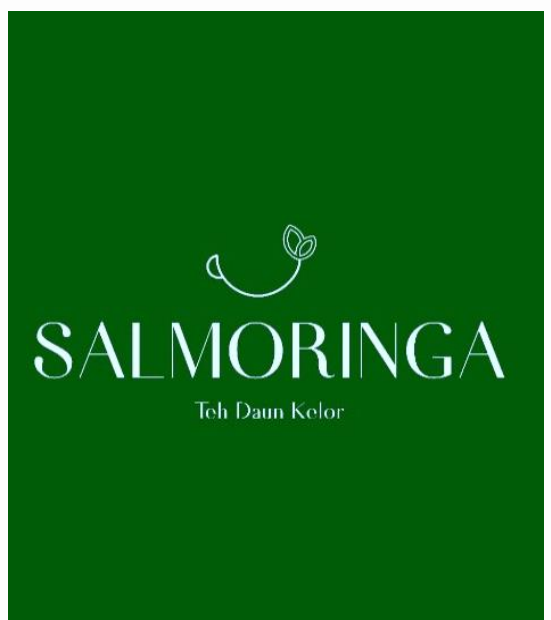

Gambar 5 label produk 


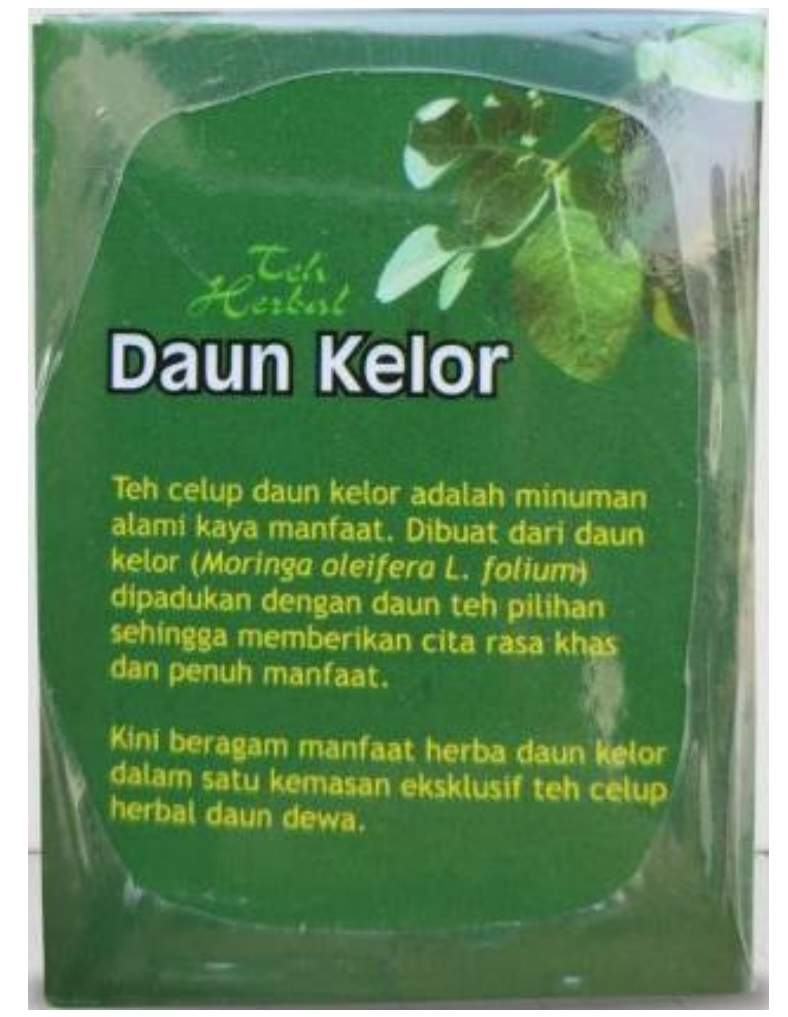

\section{Gambar 6 contoh kemasan produk Teh Kelor}

\section{KESIMPULAN}

Dari kegiatan pengabdian masyarakat yang telah dilakukan, dapat disimpulkan bahwa:

1. Pelatihan yang dilaksanakan ini berhasil meningkatkan pengetahuan dan keterampilan Pemilik UMKM Teh Kelor dan masyarakat desa Pidada, karena mulai sekarang bisa melakukan pemasaran dan penjualan produk menggunakan media sosial, sehingga pendapatan UMKM meningkat.

2. Produk UMKM Teh Kelor desa Pidada sekarang semakin dikenal oleh masyarakat di luar desa Pidada, sehingga pembeli Teh Kelor bertambah banyak.

3. Kegiatan Pengabdian Kepada Masyarakat ini sangat membantu para pemilik UMKM dalam menghadapi lesunya perekonomian selama masa Pademi Covid-19 dengan cara memasarkan produknya melalui media sosial.

\section{UCAPAN TERIMA KASIH}

Tim Pengabdi mengucapkan terima kasih kepada pemilik UMKM Teh Kelor dan warga desa Pidada Panjang Bandar Lampung yang telah memberi kesempatan untuk melakukan pengabdian ini. 


\section{DAFTAR PUSTAKA}

\section{Jurnal:}

Apriyani, M., Saty, F. M., Desfaryani, R., Fitriani, F., Trisnanto, T. B., Sutarni, Berliana, D., \& Fitri, A. (2021). Pelatihan Pengemasan Produk Olahan Pangan pada SMKN 1 Training of Processed Food Product Packaging at Vocational. Jurnal Pengabdian Nasional, 2(2), 94100.

Arifudin, D., Heryanti, L., \& Pramesti, D. (2021). Pelatihan Desain Mockup dan Logo Sebagai Branding Produk untuk Meningkatkan Nilai Jual bagi UMKM. JMM (Jurnal Masyarakat Mandiri), 5(5), 3-9.

Dumadi, D., Utami, M. D., \& Mulyani, I. D. (2021). Peningkatan Pengetahuan Mengenai Manfaat Pelabelan pada Kemasan Produksi Nugget Telor Asin. JAMU: Jurnal Abdi Masyarakat UMUS, 2(01), 65-71.

Fauzi, R. U. A., Kadi, D. C. A., Ernanda, G. K. S., Triwidya, P., \& Adhelia, S. (2021). Keefektifan Peran Digital Marketing Melalui Media Sosial Dalam Proses Pemasaran Produk Galeri UMKM Ekawira, Kare Madiun. Indonesia Berdaya, 2(1), 21-30. https://doi.org/10.47679/ib.202176

Lusianingrum, F. P. W., Purbohastuti, A. W., \& Hidayah, A. A. (2021). Pelatihan labeling kemasan produk UMKM mitra binaan Posyantek Al-Ikhlas. JMM (Jurnal Masyarakat Mandiri), 5(2), 624-632.

Panuntun Utami, D. (2021). Strategi Branding Untuk Membangun Image Positif Pangan Lokal Bagi Usaha Mikro Kecil Dan Menengah. Journal of Food Technology and Agroindustry, 3(1), 26-35.

Suprayogi, S., Sabrina, N. M., Hadi, M. S., Firdausyi, A., Nurdiansyah, I., Ismail, K. M., \& Putra, F. (2021). Diseminasi Teknologi Pengemasan untuk Meningkatkan Daya Saing Produk Olahan Pangan pada "KWT Sri Tanjung", Sukosari, Kasembon, Malang Dissemination of Packaging Technology to Improve the Food Products Abstrak. JUARA: Jurnal Wahana Abdimas Sejahtera, 2(2), 124-136. https://doi.org/10.25105/juara.v2i2.9815

Surenggono, S., Erdiana, A., \& Djamilah, S. (2021). Pemanfaatan Media Sosial Sebagai Strategi UMKM dalam Meningkatkan Penjualan di Masa Pandemi COVID 19. Jurnal Pengabdian Dharma Laksana Mengabdi Untuk Negeri, 4(1), 6. 